\title{
Detection of aluminium in different culinary media using black Eriochrome $\mathbf{T}$
}

\author{
Jacques SAWADOGO ${ }^{1 *}$, Abdoulkadri AYOUBA MAHAMANE ${ }^{3}$, \\ Dasmané BAMBARA ${ }^{1}$, Aminata KABORE ${ }^{1}$, Souley Kallo MOUTARI ${ }^{3}$, Koussao SOME$^{1}$ \\ and Jean Boukari LEGMA ${ }^{2}$
}
${ }^{I}$ Centre National de la Recherche Scientifique et Technologique/Institut de l'Environnement et de Recherches Agricoles (CNRST/INERA), GRNSP, 01 BP 476 Ouagadougou 01, Burkina Faso.
${ }^{2}$ Université Saint - Thomas - d'Aquin (USTA), Faculté des Sciences et Technologies, O6 BP 10212 Ouagadougou 06, Burkina Faso.
${ }^{3}$ Faculté de Sciences et Techniques, Université Abdou Moumouni, Niamey, BP 10662, Niger.
*Corresponding author; E-mail: jacquischimie@gmail.com; genetraore@univ-ouaga.bf

GSM: (+226) 77088989

\begin{abstract}
Local kitchen utensils are usually used in the preparation of food in Burkina Faso. The interactions between food and aluminium local kitchen utensils can be a potential source of aluminium released which can contribute to aluminium ingestion in the human body. Hence, it is important to identify the possible effects of such an interaction. The aim of this study was to determine the quantity of aluminium released in local culinary media used in Burkina Faso employing black Eriochrome T (BET). The results showed that the aluminium contents in cooked food vary according to the cooking media, the temperature and the cooking duration but were below standard rate. Moreover, the results showed that aluminium leaching was higher in salted solutions than in the other boiling media. This is probably related to the presence of chloride ions in this media. But, the results of this study suggest that there is a little concern about possible aluminium accumulation in different culinary media.
\end{abstract}

(C) 2017 International Formulae Group. All rights reserved.

Keywords: Aluminium, colorimetric, cooking, local kitchen utensils, BET, Burkina Faso.

\section{INTRODUCTION}

In most of African household and particularly those of Burkina Faso, artisanal kitchen utensils made from aluminium are indispensable to food cooking. However, data on the concentration of aluminium from local kitchen utensil in food are very scarce, even non-existent, although these containers are routinely employed to cook foods. Rajwanshi and al (Rajwanshi et al., 1997) showed that aluminium was considered as an element without impact on human health and its toxicological report of assessment have been presented in the report of Expert Committee JECFA (FAO/OMS) on additives (WHO Expert Committee on Food Additives, 2007) but it is no longer the case. Since temporary tolerance of weekly consummation of $7 \mathrm{mg} / \mathrm{kg}$ of body weight has been established for aluminium, collecting and analysing data appear important on this material. Aluminium is the most abundant metallic element and the 
third constituent of the Earth's crust (8\% of his weight) after oxygen (47\%) and silicon (28\%). However, at natural state, aluminium is never been found in the form of reactive metal, it is always combined to other elements. Cooking food using aluminium as a kitchen utensil is common. According to Yokel and McNamana (Yokel et al., 2001) who observed that foods are main sources of aluminium consumption, this practice is not advisable. Recent research suggested a correlation between aluminium ingestion at by human and Alzheimer diseases (Jansson, 2001; Andreatta et al., 2004; Gupta et al., 2005). Therefore, good practices while using cooking material need to be adopted to preserve consumers' health. Aluminium based cooking utensils are particularly the case especially when using dish cooking in oven. Yet, there is little information on the effect of cooking on local kitchen utensil of aluminium. According to literature, using container of aluminium such as kitchen utensil in cooking or stock foods can lead to the migration of aluminium in foods (Diouf et al., 2015; Sawadogo et al., 2016). That is particularly true for acids or spiced foods, cooked foods at high temperature. Aluminium is also an excellent thermal conductive local kitchen utensil particularly used in Burkina Faso. Different method of making has been developed to provide various forms of aluminium kitchen utensil (Sawadogo et al., 2014; Sawadogo, 2015). In Burkina Faso, the artisanal techniques that polish the utensil in one is popular. This technique allows making local kitchen utensil of different forms. The aim of study is to detect, according to temperature, media and cooking duration, loss of aluminium content using Black Eriochrome $\mathrm{T}$ in 4 different media of cooking. This analysis made after assess data on weight loss of different sample of aluminium collected in different culinary media (Sawadogo et al., 2015). At last, expected results should help us to better understand the impact of use of local kitchen utensil on food quality. The results are expected to help improving the material quality therefore reducing possible risk of food poisoning by aluminium during cooking. The current standard tolerate maximal concentration is 7.4 $\mu \mathrm{mol} / \mathrm{L}$ for drinking water (Barthélémy et al., 2007; Al Zubaidy et al., 2011).

\section{MATERIALS AND METHODS Principle}

Black Eriochrome $\mathrm{T}$ is a sodium salt of dihydroxyzoic sulfonate colour. In the presence of colored indicator (Karbouj, 2007; Mahob et al., 2014), diluted aluminium in the buffer solution of $\mathrm{pH} \leq 6$ produces a complex which changes at wine-colored. The formed complex is more stable. Acidity of the obtained solution depended on aluminium content. The various measures of aluminium content in culinary media will be done by colorimetric with a spectrophotometer 7315 ok JEWAY mark at $560 \mathrm{~nm}$ wavelength (Jones et al., 1957; Guillaumin et al., 2000; Sangale et al., 2014).

\section{Samples}

In order to realize this study, 4 local kitchen utensils were bought in the artisanal shop of Ouagadougou (Burkina Faso) in 2013. These sample have well-known composition (Sawadogo et al., 2016) and are named as following: A : utensil 1; B : utensil 2; C : utensil 3 ; D: utensil 4 of average dimension each 10,5 $\mathrm{cm} \times 13,5 \mathrm{~cm} \times 2 \mathrm{~cm}$ (height $\times$ diameter $\times$ thickness) (Figure 1 ).

\section{Reagents}

The aluminium standard solution used was a salt of aluminium $\mathrm{AlCl}_{3} \cdot 6 \mathrm{H}_{2} \mathrm{O}$ solid dissolved in one litter of distilled water (it releases aluminium ion $\mathrm{Al}^{3+}$ during dissolution in water solution). We took a volume that was diluted 100 times in order to obtain $100 \mathrm{ml}$ of solution called $\mathrm{S}_{0}$ (Xiao et al., 2005; Snyder, 2008; Karbouj et al., 2009). This solution contained $10 \mathrm{ppm}$ of aluminum. The solution used as buffer is acetyl acetic acid $\left(\mathrm{C}_{4} \mathrm{H}_{6} \mathrm{O}_{3}\right)$ adjusted with ascorbic acid $\left(\mathrm{C}_{6} \mathrm{H}_{8} \mathrm{O}_{6}\right)$ at $2 \%$ to have a $\mathrm{pH}=6$ (Xiao et 
al., 2005). The heating had been realizing with a butane gas stove (SODIGAZ) used in most of Burkina Faso household in food cooking.

\section{Study solution}

To simulate similar Burkina Faso operation, test of weight loss has been carried out in 4 different solutions according to the literature (Sawadogo et al., 2016):

Tape water called $\mathrm{O}$; titrated tape water at $3 \mathrm{~g} / \mathrm{l}$ called OS ; tape water mixed with tomatoes concentrated called $\mathrm{C}$ and tape water mixed with breeze rice called OR. Cooking making in most duration at hot, the different solution are tested at boiling temperatures to simulate the reel cooking conditions (Pao et al., 2001; Turhan, 2006; Sawadogo et al., 2014).

\section{Calibration curve}

The calibration curve was obtained by preparing an aluminium standard solution. This main solution of $10 \mathrm{ppm}$ metal aluminium has been dissolved on 0.0895 grams of $\mathrm{AlCl}_{3} \cdot 6 \mathrm{H}_{2} \mathrm{O}$ solid in one litter of distiller water. To elaborate the standard range, diluted solutions of solution $\mathrm{S}_{0}$ have been prepared. A total, 12 graduated flask of $50 \mathrm{ml}$, which 11 containing increasing quantity of aluminium and one as a control sample specified in Table 1. After homogenization and a wait time of 15 minutes, samples are analysed by spectrophotometry. The absorbance measured has permitted to draw the standard curve which equation allowed calculating values of concentration (Figure 2).

\section{Aluminium quantitative analysis method}

Local kitchen utensils samples A, B, C and $\mathrm{D}$ have been thoroughly washed and rinsed using distilled water then air dried.

\section{Aluminium migration}

Each kitchen utensil contained the solution $\mathrm{O}$ during 24 hour at room temperature. The same operations were realized with solution OS, TC and OR.

\section{Temperature's influence}

Each kitchen utensil has been filled out with studied solution O, OS, TC and OC then heated at boiling temperatures. To compensate evaporation during heating phase, the final volume is adjusted to the end of each operation with distilled water (Joshi et al., 2003; Shabestari, 2004; Tchegueni et al., 2012; Sawadogo, 2015).

\section{Salt influence}

Each local kitchen utensil has been filled out with solution $\mathrm{O}$ cooking fine salt was added. The whole solution was carried to the boiling temperatures during 60 minutes then cooled down at room temperature. The same operations were realized with TC and OR solution.

\section{Cooking time influence on aluminium released}

Colorimetric analyse samples has been carried out after 15 minutes, 30 minutes and 60 minutes of cooking at boiling temperatures in all 4 solutions.

\section{Colorimetric dosage of aluminium released from local kitchen cooking}

The loss of aluminium quantity released from 4 local kitchen utensils was determined by colorimetric dosage to $5 \mathrm{~mL}$ sample for each cooking solution. For that it was placed in the graduated flask of $50.0 \mathrm{ml}$ containing $10.0 \mathrm{ml}$ distilled water: $5.0 \mathrm{ml}$ of NET solution, $20.0 \mathrm{ml}$ of buffer solution acetyl acetic acid $\left(\mathrm{C}_{4} \mathrm{H}_{6} \mathrm{O}_{3}\right)$ permit to hold a $\mathrm{pH}$ at $6 ; 1.0 \mathrm{ml}$ ascorbic acid $2 \%$ and a volume of solution $S_{0}$ specified in Table 2 then filled up to the line of gauge with distilled water. After stirring and resting during 20 minutes, samples were analysed with spectrophotometer. The standard was measured with a solution without aluminium and tally with no absorbance. The concentration of aluminium in the different solution was expressed in $\mathrm{mg} / \mathrm{l}$.

\section{Data analysis}

Data obtained were analysed for duration and temperature variations using the Student's t-test and XLSTAT 7.5.2 statistical software. Mean parameters concentrations were compared according to the Ryan-EinotGabriel-Welsh (REGWQ) test. 

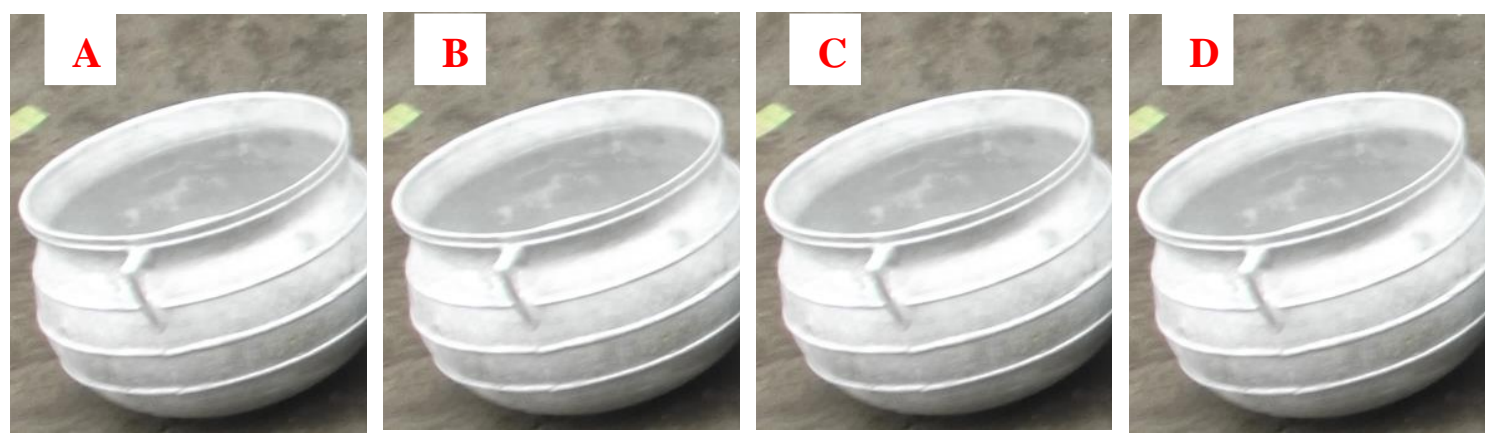

Figure 1: Sample of local kitchen utensil.

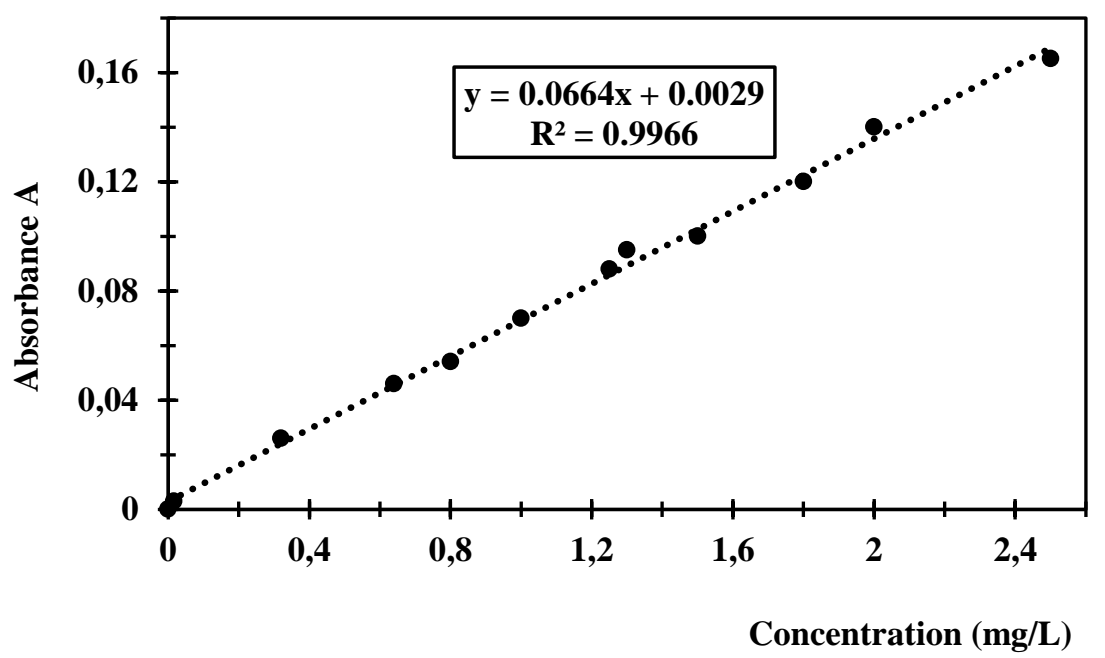

Figure 2: Standard curve for determination of aluminum by BET.

Table 1: Standard range of absorbance.

\begin{tabular}{lccc}
\hline Solutions & $\mathrm{C}=\left[\mathrm{Al}^{3+}\right](\mathrm{mg} / \mathrm{L})$ & Absorbance $(\mathbf{A})$ & $\mathrm{A} / \mathrm{C}(\mathrm{L} / \mathrm{mg})$ \\
\hline $\mathbf{S}_{\mathbf{1}}$ (Control) & 0 & 0 & $/$ \\
$\mathbf{S}_{\mathbf{2}}$ & 0.016 & 0.003 & 0.188 \\
$\mathbf{S}_{\mathbf{3}}$ & 0.320 & 0.026 & 0.081 \\
$\mathbf{S}_{\mathbf{4}}$ & 0.640 & 0.046 & 0.072 \\
$\mathbf{S}_{\mathbf{5}}$ & 0.800 & 0.054 & 0.068 \\
$\mathbf{S}_{\mathbf{6}}$ & 1.000 & 0.070 & 0.070 \\
$\mathbf{S}_{\mathbf{7}}$ & 1.250 & 0.088 & 0.070 \\
$\mathbf{S}_{\mathbf{8}}$ & 1.300 & 0.095 & 0.073 \\
$\mathbf{S}_{\mathbf{9}}$ & 1.500 & 0.100 & 0.067 \\
$\mathbf{S}_{\mathbf{1 0}}$ & 1.800 & 0.120 & 0.067 \\
$\mathbf{S}_{\mathbf{1 1}}$ & 2.000 & 0.140 & 0.07 \\
$\mathbf{S}_{\mathbf{1 2}}$ & 2.500 & 0.1650 & 0.066 \\
\hline Average value of $\mathbf{A} / \mathbf{C}$ & & & $\mathbf{0 . 0 8 1}$ \\
\hline
\end{tabular}


Table 2: composition of standard scale.

\begin{tabular}{lcccccccccccc}
\hline & $\begin{array}{c}\text { Control } \\
\text { sample }\end{array}$ & $\mathbf{S}_{\mathbf{2}}$ & $\mathbf{S}_{\mathbf{3}}$ & $\mathbf{S}_{\mathbf{4}}$ & $\mathbf{S}_{\mathbf{5}}$ & $\mathbf{S}_{\mathbf{6}}$ & $\mathbf{S}_{\mathbf{7}}$ & $\mathbf{S}_{\mathbf{8}}$ & $\mathbf{S}_{\mathbf{9}}$ & $\mathbf{S}_{\mathbf{1 0}}$ & $\mathbf{S}_{\mathbf{1 1}}$ & $\mathbf{S}_{\mathbf{1 2}}$ \\
\hline Volume of $\mathbf{S}_{\mathbf{0}}(\mathbf{m L})$ & 0 & 0.08 & 1.6 & 3.2 & 4 & 5 & 6.25 & 6.5 & 7.5 & 9 & 10 & 12.5 \\
Distilled water & 10 & 10 & 10 & 10 & 10 & 10 & 10 & 10 & 10 & 10 & 10 & 10 \\
NET (mL) & 5 & 5 & 5 & 5 & 5 & 5 & 5 & 5 & 5 & 5 & 5 & 5 \\
Buffer $\mathbf{~ p H ~ = ~ 6 ~ ( m L ) ~}$ & 15 & 15 & 15 & 15 & 15 & 15 & 15 & 15 & 15 & 15 & 15 & 15 \\
Ascorbic acid 2\% (mL) & 1 & 1 & 1 & 1 & 1 & 1 & 1 & 1 & 1 & 1 & 1 & 1 \\
\hline $\begin{array}{l}\text { Complete distilled } \\
\text { water (mL) }\end{array}$ & 50 & 50 & 50 & 50 & 50 & 50 & 50 & 50 & 50 & 50 & 50 & 50 \\
\hline $\begin{array}{l}\text { Al concentration } \\
(\mathbf{m g} / \mathbf{L})\end{array}$ & 0 & 0.016 & 0.032 & 0.64 & 0.8 & 0.1 & 1.25 & 1.3 & 1.5 & 1.8 & 2 & 2.5 \\
\hline
\end{tabular}

\section{RESULTS AND DISCUSSION}

Values of each measure are a mean of 4 absorbance measurement for each series.

\section{Standard device of measure}

For the better application to the dosage method of aluminium ion in our various solutions got after 24 hours of resting and at boiling temperatures, it is necessary to proceed to the standardization of the spectrophotometer. This is to be sure of reliability of measurement. This operation is realized using the absorbance for different concentrations of $\mathrm{Al}^{3+}$ ion. Standard solutions must have the same power ionic. Results are giving in the following Table 2 .

The corresponding curve from Table 1 is represented in Figure 2. This curve is linear, explaining that the spectrophotometer can be used to determinate the unknown content $\mathrm{Al}^{3+}$ ion in cooking solution used.

\section{Influence of temperature}

The leaching of aluminium from the 4 samples are determined using spectrocolorimetric method. ANOVA results using Ryan-Einot-Gabriel-Welsh (REGWQ) test (critical value is 4.991) to compare aluminium average contents to 4 samples are presented in the Tables 3, 4, 5 and 6. Values carrying the same letter have not significantly different according the test of REGWQ. These tables showed that the 4 types of local kitchen utensil sample, the difference of means is significant for all media.

The results from the different table lead to the following conclusions:

$\checkmark$ In each of the 4 cooking media types, once stocked in different local kitchen cooking utensils at room temperature, there are a low increase of aluminium loss, but insignificant during the 24 hours stocking period. This insignificant change of aluminium content at room temperature must be partly caused by protector layer of aluminium (alumina) against whatever possible corrosion.

$\checkmark$ Loss aluminium quantity in the media $\mathrm{O}$ after a cooking time to 15 minutes for local kitchen cooking utensils $\mathrm{A}, \mathrm{B}, \mathrm{C}$ and $\mathrm{D}$ are respectively $51.52 \mathrm{mg} / \mathrm{l}, 51.48 \mathrm{mg} / \mathrm{l}$, $50.74 \mathrm{mg} / \mathrm{L}$ and $51.13 \mathrm{mg} / \mathrm{l}$, and $51.22 \mathrm{mg} / \mathrm{l}$ as average.

Results got showed that aluminium content loss are 10 minutes more increased after 15 minutes of cooking in all study media compared with released quantity after 24 hours in contact at room temperature. This showed that aluminium quantity increases with cooking duration at boiling temperature. These results corroborate those found by some authors that showed the migration of 
aluminium in long duration and big fire cooked foods during aluminium used (Batis et al., 2003; Mareci et al., 2006; Al Zubaidy et al., 2011). Observed that aluminium content increase with cooking duration, we have chosen to fix the time to 30 minutes then 60 minutes for the following studies. As shown in Tables 4, 5 and 6.

\section{Influence of media $\mathrm{O}, \mathrm{OS}, \mathrm{TC}$ and $\mathrm{OR}$}

Aluminium content released after 30 minutes and 60 minutes in various cooking media is given in Tables 3, 4, 5 and 6 .

The same absorbance measured 30 minutes and 60 minutes of cooking duration in the media OS (titrated at $3 \mathrm{~g} / \mathrm{l}$ of salt) has given more important result in the others media (O, TC, OR) of study. The high quantity of aluminium in this media has been probably linked to the presence of chloride ion and also to environmental $\mathrm{pH}$. According to the study conducted by Bommersbach and Duggan (Duggan et al., 1992; Bommersbach, 2005) similar increase of aluminium loss with the increase of alcohol-free drinks acidity package in the aluminium bottle. Thus, according to the different tables, for the media OS, obtained contents are respectively for the 4 kitchen utensils $63.32 \mathrm{mg} / \mathrm{l} ; 62.86 \mathrm{mg} / \mathrm{l}$; $62.38 \mathrm{mg} / \mathrm{l}$ and $62.78 \mathrm{mg} / \mathrm{l}$ either an average of $62.84 \mathrm{mg} / \mathrm{l}$. Besides, for the local kitchen utensil A, B, C and D, lost aluminium contents after 60 minutes of cooking are respectively $70.62 \mathrm{mg} / \mathrm{l} ; \quad 70.28 \mathrm{mg} / \mathrm{l} ; \quad 70.38 \mathrm{mg} / \mathrm{l}$ and $70.78 \mathrm{mg} / \mathrm{l}$ for an average of $70.52 \mathrm{mg} / \mathrm{l}$. These contents are very comparable with those got using tape water, concentrated tomato and media OR in the same conditions. Other minerals in the tape water added to chloride ion have a significant influence on aluminium leaching with local kitchen utensils. For media
OR important contents of aluminium had been lost in the cooking media after 30 minutes to 60 minutes in the 4 local kitchen utensils. These results are similar to those decrypted by some authors (Müller et al., 1993; Müller et al., 1998; Mei et al., 1993; Sawadogo et al., 2016), in cooking breaking rice (OR) found to be not aggressive operation for sample containing more silicon.

For the media TC, aluminium quantities leached after a duration of cooking of 30 minutes and 60 minutes are respectively for utensils A, B, C and D increased and are 10 times higher than those of the room temperature. But these aluminium quantities released in the media are lower than media OR and OS. Studies showed that concentrated tomatoes caused more effect on cooking utensils (Karbouj, 2007; Zidane et al., 2011). Acidity of this product is so probability equivalent to those of fresh tomatoes, that is surely again a consequence of their origin and mode of production (Sawadogo et al., 2016). Contributions of water at room temperature and tomato are so low that aluminium quantities swallowed and are relatively independent form the proportion of rice water. But, toxicity norm by some authors (Chen et al., 2006; Etteyeb et al., 2007) do state of acceptable daily dose to $1 \mathrm{mg}$ by kilogram of body weight for human. This dose is a maximal tolerable quantity by human organism above which aluminium became toxic for him (Woodson, 1998; Ramdé et al., 2008; Sawadogo et al., 2014). This simplified outcome showed that we are far from the critical threshold for which human health is in danger. From this study, we can conclude that kitchen cooking utensils in Burkina Faso have not involved in particular toxicological danger. 
Table 3: Aluminium content ( $\mathrm{g} / \mathrm{L}$ ) measured in various cooking media of sample A after different contact times at room temperature $\left(25^{\circ} \mathrm{C}\right)$ and at boiling temperature.

\begin{tabular}{|c|c|c|c|c|c|c|c|c|c|}
\hline \multirow[t]{2}{*}{ Sample } & \multirow[t]{2}{*}{ Times } & \multicolumn{2}{|c|}{$\mathbf{O}$} & \multicolumn{2}{|c|}{ OS } & \multicolumn{2}{|c|}{ TC } & \multicolumn{2}{|c|}{ OR } \\
\hline & & $25^{\circ} \mathrm{C}$ & $100^{\circ} \mathrm{C}$ & $25^{\circ} \mathrm{C}$ & $100^{\circ} \mathrm{C}$ & $25^{\circ} \mathrm{C}$ & $100^{\circ} \mathrm{C}$ & $25^{\circ} \mathrm{C}$ & $100^{\circ} \mathrm{C}$ \\
\hline & 1440 & $5.15^{\mathrm{i}}$ & & $5.78^{\mathrm{i}}$ & & $5.23^{\mathrm{kl}}$ & & $5.23^{\mathrm{j}}$ & \\
\hline \multirow[t]{3}{*}{$\mathbf{A}$} & 15 & & $51.52^{\mathrm{f}}$ & & $58.29^{\mathrm{g}}$ & & $52.50^{\mathrm{h}}$ & & $52.15^{\mathrm{hi}}$ \\
\hline & 30 & & $55.35^{\mathrm{d}}$ & & $63.32^{\mathrm{d}}$ & & $56.29^{f}$ & & $56.69^{\mathrm{e}}$ \\
\hline & 60 & & $63.14^{\mathrm{c}}$ & & $70.62^{\mathrm{ab}}$ & & $63.64^{\mathrm{b}}$ & & $64.21^{\mathrm{a}}$ \\
\hline ddl & & \multicolumn{2}{|c|}{3} & \multicolumn{2}{|c|}{3} & \multicolumn{2}{|c|}{3} & \multicolumn{2}{|r|}{3} \\
\hline probability & & \multicolumn{2}{|c|}{$<0.0001$} & \multicolumn{2}{|c|}{$<0.0001$} & \multicolumn{2}{|c|}{$<0.0001$} & \multicolumn{2}{|c|}{$<0.0001$} \\
\hline meaning & & \multicolumn{2}{|c|}{ HS } & \multicolumn{2}{|c|}{ HS } & \multicolumn{2}{|c|}{ HS } & \multicolumn{2}{|c|}{ HS } \\
\hline
\end{tabular}

Table 4: Aluminium content $(\mathrm{g} / \mathrm{L})$ measured in various cooking media of sample B after different contact times at room temperature $\left(25^{\circ} \mathrm{C}\right)$ and at boiling temperature.

\begin{tabular}{|c|c|c|c|c|c|c|c|c|c|}
\hline \multirow{2}{*}{ Sample } & \multirow[t]{2}{*}{ Times } & \multicolumn{2}{|c|}{$\mathbf{O}$} & \multicolumn{2}{|c|}{ OS } & \multicolumn{2}{|c|}{ TC } & \multicolumn{2}{|c|}{ OR } \\
\hline & & $25^{\circ} \mathrm{C}$ & $100^{\circ} \mathrm{C}$ & $25^{\circ} \mathrm{C}$ & $100^{\circ} \mathrm{C}$ & $25^{\circ} \mathrm{C}$ & $100^{\circ} \mathrm{C}$ & $25^{\circ} \mathrm{C}$ & $100^{\circ} \mathrm{C}$ \\
\hline & 1440 & $5.13^{\mathrm{i}}$ & & $5.77^{\mathrm{i}}$ & & $5.25^{\mathrm{k}}$ & & $5.16^{\mathrm{j}}$ & \\
\hline \multirow[t]{3}{*}{ B } & 15 & & $51.48^{\mathrm{f}}$ & & $58.21^{\mathrm{g}}$ & & $52.78^{\mathrm{g}}$ & & $52.09^{\mathrm{i}}$ \\
\hline & 30 & & $55.13^{\mathrm{e}}$ & & $62.86^{\mathrm{e}}$ & & $56.87^{\mathrm{e}}$ & & $56.18^{f}$ \\
\hline & 60 & & $63.38^{\mathrm{a}}$ & & $70.28^{c}$ & & $63.78^{\mathrm{a}}$ & & $63.81^{\mathrm{c}}$ \\
\hline ddl & & \multicolumn{2}{|c|}{3} & \multicolumn{2}{|c|}{3} & \multicolumn{2}{|c|}{8} & \multicolumn{2}{|c|}{3} \\
\hline probability & & \multicolumn{2}{|c|}{$<0.0001$} & \multicolumn{2}{|c|}{$<0.0001$} & \multicolumn{2}{|c|}{$<0.0001$} & \multicolumn{2}{|c|}{$<0.0001$} \\
\hline meaning & & \multicolumn{2}{|c|}{ HS } & \multicolumn{2}{|c|}{ HS } & \multicolumn{2}{|c|}{ HS } & \multicolumn{2}{|c|}{ HS } \\
\hline
\end{tabular}

* results are means of 3 repetitions ;*HS = high significant, Test Ryan-Einot-Gabriel-Welsch (REGWQ) the difference is not significant between values added by the same letter in the same line.

Table 5: Aluminium content $(\mathrm{g} / \mathrm{L})$ measured in various cooking media of sample $\mathrm{C}$ after different contact times at room temperature $\left(25^{\circ} \mathrm{C}\right)$ and at boiling temperature.

\begin{tabular}{|c|c|c|c|c|c|c|c|c|c|}
\hline \multirow[t]{2}{*}{ Sample } & \multirow[t]{2}{*}{ Times } & \multicolumn{2}{|c|}{$\mathbf{O}$} & \multicolumn{2}{|c|}{ OS } & \multicolumn{2}{|c|}{ TC } & \multicolumn{2}{|c|}{ OR } \\
\hline & & $25^{\circ} \mathrm{C}$ & $100^{\circ} \mathrm{C}$ & $25^{\circ} \mathrm{C}$ & $100^{\circ} \mathrm{C}$ & $25^{\circ} \mathrm{C}$ & $100^{\circ} \mathrm{C}$ & $25^{\circ} \mathrm{C}$ & $100^{\circ} \mathrm{C}$ \\
\hline & 1440 & $4.98^{\mathrm{j}}$ & & $5.87^{\mathrm{i}}$ & & $5.17^{\mathrm{lm}}$ & & $5.20^{\mathrm{j}}$ & \\
\hline \multirow[t]{3}{*}{$\mathrm{C}$} & 15 & & $50.74^{\mathrm{h}}$ & & $57.62^{\mathrm{h}}$ & & $52.12^{\mathrm{j}}$ & & $52.23^{\mathrm{h}}$ \\
\hline & 30 & & $55.29^{\mathrm{d}}$ & & $62.38^{\mathrm{f}}$ & & $57.06^{\mathrm{d}}$ & & $56.26^{\mathrm{f}}$ \\
\hline & 60 & & $63.24^{\mathrm{b}}$ & & $70.38^{\mathrm{bc}}$ & & $63.48^{\mathrm{c}}$ & & $64.08^{\mathrm{b}}$ \\
\hline ddl & & & 3 & & 3 & & & & 3 \\
\hline Probability & & & 0001 & & .0001 & & & & 0001 \\
\hline Manning & & & IS & & HS & & & & IS \\
\hline
\end{tabular}


Table 6: Aluminium content measured in various cooking media of sample D after different contact times at room temperature $\left(25^{\circ} \mathrm{C}\right)$ and at boiling temperature.

\begin{tabular}{|c|c|c|c|c|c|c|c|c|c|}
\hline \multirow[t]{2}{*}{ Sample } & \multirow[t]{2}{*}{ Times } & \multicolumn{2}{|c|}{$\mathbf{O}$} & \multicolumn{2}{|c|}{ OS } & \multicolumn{2}{|c|}{ TC } & \multicolumn{2}{|c|}{ OR } \\
\hline & & $25^{\circ} \mathrm{C}$ & $100^{\circ} \mathrm{C}$ & $25^{\circ} \mathrm{C}$ & $100^{\circ} \mathrm{C}$ & $25^{\circ} \mathrm{C}$ & ${ }_{100^{\circ} \mathrm{C}}$ & $25^{\circ} \mathrm{C}$ & $100^{\circ} \mathrm{C}$ \\
\hline & 1440 & $5.10^{\mathrm{i}}$ & & $5,84^{\mathrm{i}}$ & & $5.12^{\mathrm{m}}$ & & $5.24^{\mathrm{j}}$ & \\
\hline \multirow[t]{3}{*}{ D } & 15 & & $51.13^{\mathrm{g}}$ & & $57.85^{\mathrm{h}}$ & & $52.25^{\mathrm{i}}$ & & $52.39^{\mathrm{g}}$ \\
\hline & 30 & & $55.19^{\mathrm{e}}$ & & $62.78^{\mathrm{e}}$ & & $56.96^{\mathrm{e}}$ & & $56.82^{\mathrm{d}}$ \\
\hline & 60 & & $63.32^{\mathrm{ab}}$ & & $70.78^{\mathrm{a}}$ & & $63.42^{\mathrm{c}}$ & & $64.24^{\mathrm{a}}$ \\
\hline ddl & & \multicolumn{2}{|c|}{3} & \multicolumn{2}{|c|}{3} & \multicolumn{2}{|c|}{3} & \multicolumn{2}{|c|}{3} \\
\hline Probability & & \multicolumn{2}{|c|}{$<0.0001$} & \multicolumn{2}{|c|}{$<0.0001$} & \multicolumn{2}{|c|}{$<0.0001$} & \multicolumn{2}{|c|}{$<0.0001$} \\
\hline Manning & & \multicolumn{2}{|c|}{ HS } & \multicolumn{2}{|c|}{ HS } & \multicolumn{2}{|c|}{ HS } & \multicolumn{2}{|c|}{ HS } \\
\hline
\end{tabular}

* results are means of 3 replications; ${ }^{*} \mathrm{HS}=$ high significant, Test Ryan-Einot-Gabriel-Welsch (REGWQ) the difference is not significant between values added by the same letter in the same line.

\section{Conclusion}

This work is a contribution to the colorimetric determination of aluminium in various cooking media using Black Eriochrome T. This method permitted to know that aluminium released during cooking in used local kitchen utensils of aluminium. Analysis of 4 local kitchen utensils with known composition and with various cooking media frequently used in Burkina Faso showed that aluminium content released increases with temperature influence, cooking time and media. However, insignificant values of aluminium concentration released at room temperature in all solution are may be caused by the short stocking time, may be a decreasing of stocking temperature or another factor not deal with in this study. This study permits to update literature data and must support agribusiness and socio-economic interest of local kitchen utensils made in Burkina Faso according to the area. As precaution to take for limit risk of aluminium migration in foods:

$\checkmark$ Avoid using spoil kitchen utensils, aluminium migrate more easily when kitchen utensils are worn;

$\checkmark \quad$ Avoid cooking or preserving food in kitchen utensil in aluminium. Food will absorb more aluminium if it is cooked or preserved in kitchen utensil (pan, leaf...) made in this material ;
Avoid to cook vegetable or acid foods as tomatoes, citrus fruit in aluminium utensil, products absorb more easily this material.

\section{COMPETING INTERESTS}

All authors declare that they have no competing interests.

\section{AUTHORS' CONTRIBUTIONS}

JS collected the samples, run the analysis in the laboratory, run the statistical analysis and wrote the manuscript (35\%). AAM contributed to design the methodology (all authors agreed on the method to use for sampling, sampling period and site choice). $\mathrm{He}$ also contributed to the statistical analysis and provided comments to the manuscript (15\%). DB participated in the writing and improvement of the manuscript. He also contributed to the language checking (15\%). $\mathrm{AK}, \mathrm{KS}$ and SKM read and improved the discussion section. They also provided logistical and financial assistances during the field work (10\% to each person). JBL was helpful in the laboratory works and contributed to write the methodology (5\%).

\section{ACKNOWLEDGMENTS}

Our thanks to the professor emeritus of analytical chemistry, Mr. Jean Boukari LEGMA of University Saint - Thomas 
d'Aquin - Burkina Faso that always know accompany us in scientific research.

\section{REFERENCES}

Al Zubaidy E A, Mohammad FS, Bassioni G. 2011. Effect of pH, salinity and temperature on aluminum cookware leaching during food preparation. International Journal of Electrochemical Science, 6(12): 64246441, DOI: www.electrochemsci.org.

Andreatta F, Terryn H, De Wit J, 2004. Corrosion behaviour of different tempers of AA7075 aluminium alloy. Electrochimica Acta, 49(17): 28512862, DOI: http://dx.doi.org/10.1016/ j.electacta.2004.01.046

Barthélémy E, Lafon D, Frémy J, Feigenbaum A. 2007. Les matériaux au contact des aliments: réglementation et évaluation des risques sanitaires pour les consommateurs. Archives des Maladies Professionnelles et de l'Environnement, 68(3): 267-278, DOI: https://doi.org/10.1016/S17758785(07)88941-7.

Batis G, Routoulas A, Rakanta E. 2003. Effects of migrating inhibitors on corrosion of reinforcing steel covered with repair mortar. Cement and Concrete Composites, 25(1): 109-115, DOI: https://doi.org/10.1016/S09589465(01)00047-6.

Bommersbach P. 2005. Evolution des propriétés d'un film inhibiteur de corrosion sous l'influence de la température et des conditions hydrodynamiques. Thèse de Doctorat Unique, Institut National des Sciences Appliquées de Lyon, 154 p.

Chen X, Geng H, Li Y. 2006. Study on the eutectic modification level of $\mathrm{Al}-7 \mathrm{Si}$ Alloy by computer aided recognition of thermal analysis cooling curves. Materials Science and Engineering: A, 419(1): 283-289, DOI: 10.1016/j.msea. 2005.12.036.

Diouf LAD, Ndiaye A, SY PM, Djiboune A R, Soumboundou M, Ndong B, Diop O,
Bathily EAL, Mbodj M, Gassama SS, Badiane B, Diarra M. 2015. Évaluation des quantités d'aluminium libérées à partir de marmites de fabrication artisanale. Revue du CAMES: Science de la Santé, 3(1): 4-8.

Duggan J, Dickeson J, Tynan P, Houghton A, Flynn J. 1992. Aluminium beverage cans as a dietary source of aluminium. The Medical Journal of Australia, 156(9): 604-605.

Etteyeb N, Dhouibi L, Takenouti H, Alonso M, Triki E. 2007. Corrosion inhibition of carbon steel in alkaline chloride media by $\mathrm{Na} 3 \mathrm{PO}$ 4. Electrochimica Acta, 52(27): 7506-7512, DOI: https://doi.org/10.1016/j.electacta.2007. 03.003 .

Guillaumin V, Mankowski G. 2000. Localized corrosion of 6056 T6 aluminium alloy in chloride media. Corrosion Science, 42(1): 105-125, DOI: http://dx.doi.org/10.1016/S0010938X(99)00053-0

Gupta VB, Anitha S, Hegde M, Zecca L, Garruto R, Ravid R, Shankar S, Stein R, Shanmugavelu P, Jagannatha Rao K. 2005. Aluminium in Alzheimer's disease: are we still at a crossroad? Cellular and Molecular Life Sciences, 62(2): 143-158, DOI: 10.1007/s00018004-4317-3.

Jansson ET. 2001. Aluminum exposure and Alzheimer's disease. Journal of Alzheimer's Disease, 3(6): 541-549, DOI: 10.3233/JAD-2001-3604.

Jones L, Thurman D. 1957. The determination of aluminium in soil, ash and plant materials using Eriochrome Cyanine RA. Plant and Soil, 9(2): 131142, DOI: 10.1007/BF01398921.

Joshi S, Toma R, Medora N, O'Connor K. 2003. Detection of aluminium residue in sauces packaged in aluminium pouches. Food Chemistry, 83(3): 383-386, DOI: https://doi.org/10.1016/S03088146(03)00099-2.

Karbouj R. 2007. Aluminium leaching using chelating agents as compositions of 
food. Food and Chemical Toxicology, 45(9): $\quad 1688-1693$, DOI: http://dx.doi.org/10.1016/j.fct.2007.03.0 01.

Karbouj R, Desloges I, Nortier P. 2009. A simple pre-treatment of aluminium cookware to minimize aluminium transfer to food. Food and Chemical Toxicology, 47(3): 571-577, DOI: 10.1016/j.fct.2008.12.028.

Mahob R J, Ndoumbe-Nkeng M, Ten Hoopen G M, Dibog L, Nyassé S, Rutherford M, Mbenoun M, Babin R, Mbang J A A, Yede Y. 2014. Pesticides use in cocoa sector in Cameroon: characterization of supply source, nature of actives ingredients, fashion and reasons for their utilization. International Journal of Biological and Chemical Sciences, 8(5): 1976-1989, DOI:

http://dx.doi.org/10.4314/ijbcs.v8i5.3.

Mareci D, Popa I, Ungureanu G, Aelenei D, Rosca J C M. 2006. reponse electrochimique de l'aluminium en contact avec la biere. Scientific Study and Research, VII(4): 769 - 778.

Mei L, Yao T. 1993. Aluminum contamination of food from using aluminumware. International Journal of Environmental Analytical Chemistry, 50(1): $\quad 1-8, \quad$ DOI: http://dx.doi.org/10.1080/03067319308 027577.

Müller JP, Steinegger A, Schlatter C. 1993. Contribution of aluminium from packaging materials and cooking utensils to the daily aluminium intake. Zeitschrift für Lebensmitteluntersuchung undForschung A, 197(4): 332-341, DOI: 10.1007/BF01242057.

Müller M, Anke M, Illing-Günther H. 1998. Aluminium in foodstuffs. Food Chemistry, 61(4): 419-428, DOI: 0.1016/S0308-8146(97)00085-X.

Pao P, Gill S, Feng C, Sankaran K. 2001. Corrosion-fatigue crack growth in friction stir welded Al 7050. Scripta
Materialia, 45(5): 605-612, DOI: http://dx.doi.org/10.1016/S13596462(01)01070-3.

Rajwanshi P, Singh V, Gupta M, Kumari V, Shrivastav R, Ramanamurthy M, Dass S. 1997. Studies on aluminium leaching from cookware in tea and coffee and estimation of aluminium content in toothpaste, baking powder and paan masala. Science of the Total Environment, 193(3): 243-249, DOI: https://doi.org/10.1016/S00489697(96)05347-8.

Ramdé T, Bonou L, Guel B, Legma JB. 2008. Comportement à la corrosion des alliages d'aluminium recyclés pour la confection de marmites. Journal de la Société Ouest-Africaine de Chimie, 26113-121, DOI: http://www.soachim. org.

Sangale M, Daptare S, Sonawane V. 2014. Determination of aluminum an magnesiumions in some commercial adsorptive anatacids by complexometric titrations. International Journal of Advanced Scientific and Technical Research, 4(4): 452 - 465, DOI: http://www.rspublication.com/ijst/index .html

Sawadogo J. 2015. Caractérisation physicochimique des ustensiles de cuisine fabriqués artisanalement au Burkina Faso. Thèse de Doctorat Unique, Université de Ouagadougou - Burkina Faso. 217p.

Sawadogo J, Bougouma M, Legma JB, Delplancke OMP. 2015. Determination of stoichiometry from polycrystalline powders of transition metals lamellar dichalcogenides: MoSe2, WSe2, obtained by synthesis in laboratory. International Journal of Biological and Chemical Sciences, 9(1): 454 - 471, DOI:

http://dx.doi.org/10.4314/ijbcs.v9i1.39.

Sawadogo J, Bougouma M, Mahamane A A, Maman M A, Kabore A, Pouya M B, Legma J B, Sedogo M P, 2016. La perte de masse dans divers milieux culinaires 
des ustensiles de cuisine locaux en aluminium: cas du Burkina Faso. Afrique Science, 12(3): 160 - 170, DOI: http://www.afriquescience.info.

Sawadogo J, Bougouma M, Ramdé T, Boubié G, Bonou LD, Ogletree M-PD, Legma JB. 2014. Caractérisations physico-chimiques des ustensiles de cuisine (marmites artisanales) fabriqués au Burkina Faso. Journal de la Société Ouest-Africaine de Chimie, 03718 - 28, DOI: http://www.soachim.org.

Sawadogo J, Nisol B, Bougouma M, Ramdé T, Boubié G, Buess-Hermann C, Legma JB. 2014. Caractérisations chimiques des ustensiles de cuisine artisanale en aluminium fabriqués au Burkina Faso : cas de Ouagadougou. International Journal of Biological and Chemical Sciences, 8(6): 2813 - 2827, DOI: http://dx.doi.org/10.4314/ijbcs.v8i6.38.

Shabestari S. 2004. The effect of iron and manganese on the formation of intermetallic compounds in aluminumsilicon alloys. Materials Science and Engineering: A, 383(2): 289-298, DOI: https://doi.org/10.1016/j.msea.2004.06. 022.

Snyder PO. 2008. The effect of aluminum and iron cooking utensils on food. Hospitality Institute of Technology and Management, retrieved on Aug, 81 - 2, DOI: http://www.hi-tm.com.

Tchegueni S, Kili K A, Bodjona M, Koriko M, Hafidi M, Baba G, Tchangbedji G. 2012. Effets des composts à base de déchets d'agrumes et du tourteau de karité sur la disponibilité du phosphore du sol: Une étude en conditions contrôlées. International Journal of Biological and Chemical Sciences, 6(3): 1381-1389,

DOI: http://dx.doi.org/10.4314/ijbcs.v6i3.39.
Turhan S. 2006. Aluminium contents in baked meats wrapped in aluminium foil. Meat Science, 74(4): 644-647, DOI: 10.1016/j.meatsci.2006.03.031.

WHO Expert Committee on Food Additives J F. 2007. Evaluation of certain food additives and contaminants: sixty-eighth report of the Joint FAO/WHO Expert Committee on Food Additives. : World Health Organization.

Woodson G. 1998. An interesting case of osteomalacia due to antacid use associated with stainable bone aluminum in a patient with normal renal function. Bone, 22(6): 695-698, DOI: http://dx.doi.org/10.1016/S87563282(98)00060-X.

Xiao Y, Reuter MA, Boin U. 2005. Aluminium recycling and environmental issues of salt slag treatment. Journal of Environmental Science and Health, 40(10): 1861-1875, DOI: 10.1080/10934520500183824.

Yokel RA, McNamara PJ. 2001. Aluminium toxicokinetics: an updated minireview. Basic \& Clinical Pharmacology \& Toxicology, 88(4): 159-167, DOI: https://doi.org/10.1016/S00489697(96)05347-8.

Zidane F, Rhazzar A, Blais J-F, Ayoubi K, Bensaid J, Basri SE, Kaba N, Fakhreddine Q, Lekhlif B. 2011. Contribution à la dépollution des eaux usées de textile par électrocoagulation et par adsorption sur des composés à base de fer et d'aluminium. International Journal of Biological and Chemical Sciences, 5(4): 1727-1745. 